\title{
Bone morphogenetic protein-2 exhibits therapeutic benefits for osteonecrosis of the femoral head through induction of cartilage and bone cells
}

\author{
CHUNHUI WANG ${ }^{1}$, HUIMEI ZANG ${ }^{2}$ and DONGSHENG ZHOU ${ }^{1}$ \\ ${ }^{1}$ Department of Orthopedics, Shandong Provincial Hospital Affiliated to Shandong University, Jinan, Shandong 250021; \\ ${ }^{2}$ Department of Cardiovascular Medicine, Shandong University Qilu Hospital Research Center for Cell Therapy, \\ Key Laboratory of Cardiovascular Remodeling and Function, Jinan, Shandong 250012, P.R. China
}

Received May 8, 2017; Accepted October 20, 2017

DOI: $10.3892 /$ etm.2018.5941

\begin{abstract}
Osteonecrosis of the femoral head is an orthopedic disease caused by femoral head damage or insufficient blood supply, which leads to the death of bone cells and bone marrow. Osteonecrosis of the femoral head leads to changes in the structure of the femoral head, femoral head collapse and joint dysfunction. Bone morphogenetic protein-2 (BMP-2) exhibits beneficial effects on bone formation, repair and angiogenesis at the femoral head. In the present study, the therapeutic effects of recombinant human BMP-2 containing an Fc fragment (rBMP-2/Fc) were investigated on a steroid induced mouse model of osteonecrosis of the femoral head. Bone cell viability was used to determine the in vitro effects of $\mathrm{rBMP}-2 / \mathrm{Fc}$. The therapeutic efficacies of $\mathrm{rBMP}-2 / \mathrm{Fc}$ on mice with osteonecrosis of the femoral head were evaluated using clinical arthritis scores. The expression levels of inflammatory factors in the mice were analyzed by reverse transcription-quantitative polymerase chain reaction. Histological analysis was used to evaluate the effects of $\mathrm{rBMP}-2 / \mathrm{Fc}$ on the femoral head. The results revealed that $\mathrm{rBMP}-2 / \mathrm{Fc}$ treatment significantly increased the IL-6, IL-10, vascular endothelial growth factor and macrophage colony-stimulating factor expression levels in synovial cells compared with the control group $(\mathrm{P}<0.01)$. Furthermore, it was observed that $\mathrm{rBMP}-2 / \mathrm{Fc}$ significantly improved the viability and growth of synovial cells $(\mathrm{P}<0.01)$ through the nuclear factor $(N F)-\kappa B$ signaling pathway. Treatment with $\mathrm{rBMP}-2 / \mathrm{Fc}$ significantly decreased receptor activator of $\mathrm{NF}-\kappa \mathrm{B}$ ligand expression levels. Furthermore, in vivo experiments demonstrated that $\mathrm{rBMP}-2 / \mathrm{Fc}$ treatment
\end{abstract}

Correspondence to: Professor Dongsheng Zhou, Department of Orthopedics, Shandong Provincial Hospital Affiliated to Shandong University, 324 Jingwu Road, Jinan, Shandong 250021, P.R. China

E-mail: sdorthopedics@126.com

Key words: osteonecrosis of the femoral head, recombinant bone morphogenetic protein-2/Fc fragment, nuclear factor-rag angiogenesis markedly relieved the arthralgia and damage caused by osteonecrosis of the femoral head. In conclusion, rBMP-2/Fc treatment may be beneficial for articular cartilage repair by the upregulation of angiogenesis factors through the down regulation of the NF- $\kappa \mathrm{B}$ signaling pathway in mice with osteonecrosis of the femoral head. This preclinical data suggests that $\mathrm{rBMP}-2 / \mathrm{Fc}$ may be a promising novel agent for treatment of osteonecrosis of the femoral head.

\section{Introduction}

Arthritis is a degenerative disease characterized by joint pain, tenderness, stiffness, swelling, restricted movement and joint deformities (1). There are a number of different types of arthritis, including rheumatic arthritis, rheumatoid arthritis, osteoarthritis, gouty arthritis, ankylosing spondylitis, reactive arthritis, infectious arthritis and other factor-induced arthritis $(2,3)$. In recent years, the number of osteoarthritis has risen and an increasing number of individuals have been clinically diagnosed with the condition, which presents a serious threat to human health and quality of life $(4,5)$. Osteonecrosis of the femoral head is a specific type of osteoarthritis that significantly affects the patient's ability to move and exhibits the most serious degeneration of the joints among osteonecrosis diseases $(6,7)$.

Osteonecrosis of the femoral head may be divided into different categories, including traumatic, drug-induced and alcohol-stimulated femoral head necrosis, which have different degrees of pathogenesis and disease progression $(4,8)$. Previous studies have demonstrated that osteonecrosis of the femoral head is an autoimmune disease and primarily manifests as inflammatory arthritis $(9,10)$. The causes of femoral head necrosis are diverse and complex, meaning they are difficult to comprehensively explain in a classification system. Additionally, the pathogenesis of osteonecrosis of the femoral head is not fully understood (11-13). Therefore, a variety of treatments for osteonecrosis of the femoral head have previously been proposed (14-16). Although the outcomes described in previous studies are encouraging, the failure rates remain high due to the failure of bone generation and revascularization in the femoral head (17-19). 
Bone morphogenetic proteins (BMPs) belong to the transforming growth factor- $\beta$ superfamily that regulates a number of cellular activities (20). Previous studies have demonstrated that BMPs serve important roles in different forms of arthritis and their disease activity (21-23). Grcevic et al (24) previously reported that the peripheral blood expression profiles of BMPs may act as predictive markers for the development of arthritis, its disease activity, therapeutic responsiveness and overall prognosis. Lories and Luyten (25) previously suggested that BMPs are beneficial for the repair of joint destruction and tissue responses that may form the basis of chronic arthritis. BMP-2 is a member of the BMP family that contributes to bone formation, joint anti-inflammation and synovial repair $(26,27)$. Previous research has suggested that recombinant BMP-2may induce bone formation and osteoblastic differentiation by regulating endochondral ossification $(28,29)$. In addition, abnormal expression of BMP-2 in mesenchymal cells has been investigated in association with rheumatoid arthritis (30). Furthermore, BMP-2 has been used clinically during spinal fusion procedures and treatment outcomes have indicated that it is effective in regulating joint inflammation and damage in rats and rabbits $(31,32)$. However, the in vivo effects of BMP-2 in humans are unpredictable due to its short half-life in patients with rheumatoid arthritis (33).

In the present study, the beneficial effects of recombinant BMP-2 containing the Fc fragment (rBMP-2/Fc) were investigated in a mouse model of osteonecrosis of the femoral head. The results indicated that $\mathrm{rBMP}-2 / \mathrm{Fc}$ significantly improved the viability and growth of synovial cells through the nuclear factor (NF) $-\kappa \mathrm{B}$ signaling pathway. In vivo experiments demonstrated that $\mathrm{rBMP}-2 / \mathrm{Fc}$ treatment markedly relieved the arthralgia and repaired the damaged osteonecrosis of the femoral head by promoting angiogenesis of the femoral head.

\section{Materials and methods}

Animal protocol. A total of 60 male 6-8 week old, C57BL/6J mice were purchased from Shanghai SLAC Laboratory Animal Co., Ltd. (Shanghai, China). All mice were identified by ear punching and housed in temperature-controlled room $\left(25 \pm 1^{\circ} \mathrm{C}\right.$; humidity, $\left(50 \pm 5^{\circ} \mathrm{C}\right)$ with an artificial $12 \mathrm{~h} \mathrm{light} / \mathrm{dark}$ cycle and ad libitum free access to food and water. A steroid-induced osteonecrosis of the femoral head (SI-OTFD) mouse model was established as previously described, via the subcutaneous administration of $100 \mathrm{mg} / \mathrm{kg}$ steroid (Glucocorticoid; ModiQuest Research, Oss, The Netherlands). The mice were divided into the following three groups ( $n=20$ per group): i) The control group (healthy mice), ii) the BMP-2/Fc group and iii) the dexamethasone (DEX) group (positive control). On day 7 following model establishment, the mice received treatment with either BMP-2/Fc $(10 \mathrm{mg} / \mathrm{kg}$, Sigma-Aldrich; Merck KGaA, Darmstadt, Germany), DEX (10 mg/kg; Sigma-Aldrich; Merck KGaA) or the same volume of PBS (control group) via intravenous injection. The body weights of the experimental mice were measured prior to each administration. The treatments were administered seven times, once every three days for a total of 21 days. Mice were sacrificed on day 32 for histological analysis with $100 \mathrm{mg} / \mathrm{kg} \mathrm{1 \%}$ intravenous sodium pentobarbital. Clinical osteonecrosis of the femoral head was evaluated using a scale of $0-2$ as previously described (34). A total of 10 randomly selected mice were sacrificed on day 32 and the remainder were housed for a 120-day observation. Body and spleen weights of mice were measured post-sacrifice on day 32 . Arthritic scores were measured from mice as previously described (35).

The present study was performed in strict accordance with the recommendations of the Guide for the Care and Use of Laboratory Animals of the Tianjin Medical University (36). All animal procedures were reviewed and approved by the Ethical Committee of Shandong Medical University (Shandong, China). All surgeries and euthanasia were performed under sodium pentobarbital anesthesia (1\% sodium pentobarbital, $40 \mathrm{mg} / \mathrm{kg}$, Sigma-Aldrich; Merck KGaA) by intraperitoneal injection. All efforts were made to minimize the suffering of the experimental mice.

Cells and reagents. Experimental mice were anesthetized using sodium pentobarbital anesthesia (1\% intravenous sodium pentobarbital, $40 \mathrm{mg} / \mathrm{kg}$, Sigma-Aldrich) and Synoviocytes were isolated from the experimental mice on day 32 as described previously (37) and then cultured at $37^{\circ} \mathrm{C}$ in a $5 \%$ $\mathrm{CO}_{2}$ humidified atmosphere in minimum essential medium (Sigma-Aldrich; Merck KGaA) with $10 \%$ fetal bovine serum (FBS; Sigma-Aldrich; Merck KGaA). BMP and BMP receptor (BMP-2R) were also purchased from Sigma-Aldrich (Merck $\mathrm{KGaA}$ ). Saos-2 cells were purchased from the American Type Culture Collection (Manassas, VA, USA) and cultured in Dulbecco's modified Eagle's medium (DMEM; Sigma-Aldrich; Merck KGaA) with $10 \%$ FBS for $12 \mathrm{~h}$ at $37^{\circ} \mathrm{C}$ in a $5 \% \mathrm{CO}_{2}$ humidified atmosphere. Synoviocytes from PBS-treated mice were treated with $\mathrm{rBMP}-2 / \mathrm{Fc}(10 \mathrm{ng} / \mathrm{ml}), \mathrm{BMP}-2 \mathrm{R}(10 \mathrm{ng} / \mathrm{ml})$ or PBS (Control) for $24 \mathrm{~h}$ at $37^{\circ} \mathrm{C}$ in a $5 \% \mathrm{CO}_{2}$ humidified atmosphere to analyze the activity and function of $\mathrm{rBMP}-2 / \mathrm{Fc}$ in synoviocytes.

Cell viability. Synoviocytes form experimental mice following treatment were seeded at a density of $1 \times 10^{3}$ cells/well in 96-well plates with DMEM containing $10 \% \mathrm{FBS}$ at $37^{\circ} \mathrm{C}$ for certain time periods $(12,24,36,48,60$ and 72 h). Following incubation, $20 \mu \mathrm{l}$ MTT reagent (Sigma-Aldrich; Merck $\mathrm{KGaA}$ ) in $20 \mu \mathrm{l}$ PBS was added into each well and cells were incubated at $37^{\circ} \mathrm{C}$ for $4 \mathrm{~h}$, to enable the formation of water insoluble formazan crystals. The formazan crystals were then dissolved using dimethyl sulfoxide (200 $\mu \mathrm{l} /$ well) and their absorbance (optical density, OD) at $570 \mathrm{~nm}$ was measured using a microplate spectrophotometer (Bio-Rad Laboratories, Inc., Hercules, CA, USA). The inhibition rate of cell viability was calculated using the following equation: Inhibition rate $(\%)=\left(\mathrm{OD}_{\text {control }}-\mathrm{OD}_{\text {treated }}\right) / \mathrm{OD}_{\text {control }} \mathrm{x} 100$.

Cell differentiation. Synoviocytes from sacrificed experimental mice following treatment were seeded at a density of $1 \times 10^{5}$ cells $/ \mathrm{cm}^{2}$ for $12 \mathrm{~h}$ at $37^{\circ} \mathrm{C}$. At $85 \%$ confluence, the cells were cultured in osteogenic medium (Invitrogen; Thermo Fisher Scientific, Inc., Waltham, MA, USA) containing 5\% fetal bovine serum (Gibco; Thermo Fisher Scientific, Inc.) in the presence of the aforementioned reagents. The procedures used for characterizing Synoviocyte differentiation were as described in a previous study (38). 
ELISA analysis. The concentration of vascular endothelial growth factor (VEGF; cat. no. MMV00; Bio-Rad Laboratories, Inc.), BMP-2R (MAB3552; Bio-Rad Laboratories, Inc.), receptor activator of $\mathrm{NF}-\kappa \mathrm{B}$ ligand (RANKL; cat. no, Hu7596RY; Huiying, Shanghai, China) and macrophage colony-stimulating factor (M-CSF; cat. no. KHG00112; Thermo Fisher Scientific, Inc.) In the synovial cells of experimental mice were analyzed using ELISA. Synovial cells were harvested and homogenized in an Instant One ELISA Cell Lysis Buffer (Invitrogen; Thermo Fisher Scientific, Inc.). The synovial cells were subsequently separated by centrifugation at $6,000 \mathrm{x} \mathrm{g}$ for $10 \mathrm{~min}$ at room temperature and the homogenate was quantified according to a previously described method (39). The levels of BMP-2R (cat. no. FK-R0025; Huiying), M-CSF (cat. no. KHG00112; Thermo Fisher Scientific, Inc.) and RANKL (cat. no, Hu7596RY; Huiying) were measured using ELISA according to the manufacturers' protocols. Levels of BMP-2 (cat. no. ab119582), IL-6 (cat. no. ab100712) and IL-10 (cat. no. ab100765) were assessed using ELISA kits obtained from Abcam (Cambridge, UK) according to the manufacturers' protocol.

Formation of the $r B M P 2 / F c$ protein. The human BMP-2 linked with the Fc fragment was obtained form the Department of Orthopedics, Shandong Provincial Hospital Affiliated to Shandong University (Jinan, China). The gene was sequenced by Invitrogen (Thermo Fisher Scientific, Inc.) and the BMP-2/Fc gene (200 ng) was inserted into pET27b vectors and named pET27b-BMP-2/Fc. The pET27b-BMP-2/Fc was expressed in Escherichia coli Rossetta (Invitrogen; Thermo Fisher Scientific, Inc.) by transforming the recombinant pET27b-BMP-2/Fc plasmid using electro transformation (40). The bacteria were grown in lysogeny broth medium (Invitrogen; Thermo Fisher Scientific, Inc.) for $12 \mathrm{~h}$ at $37^{\circ} \mathrm{C}$ and $0.5 \mathrm{mM}$ isopropylthio- $\beta$-d-galactoside (IPTG, Sigma-Aldrich; Merck KGaA) was used to induce BMP-2/Fc expression. Subsequently, the cells were disrupted following a $12 \mathrm{~h}$ induction with IPTG and dissolved in $15 \mathrm{ml}$ PBS. The protein underwent denaturation for $12 \mathrm{~h}$ at $90^{\circ} \mathrm{C}$ and renaturation for $12 \mathrm{~h}$ at $4^{\circ} \mathrm{C}$ and ion exchange chromatography was used to purify the protein of interest. The purified protein was collected and $1.5 \%$ gel filtration chromatography (glucan) further purified the $\mathrm{rBMP}-2 / \mathrm{Fc}$ protein.

Reverse transcription-quantitative $(R T-q) P C R$. Total RNA from the synovial cells was extracted using a RiboMinus ${ }^{\mathrm{TM}}$ Eukaryote kit (Invitrogen; Thermo Fisher Scientific, Inc.) according to the manufacturer's protocol. The concentration of RNA was quantified by spectrophotometry at $260 \mathrm{~nm}$ (SmartSpec 3000; Bio-Rad Laboratories, Inc.). The quantified RNA was subjected to RT into cDNA using a QuantiTect Reverse Transcription kit (Qiagen Sciences, Inc., Gaithersburg, MD, USA) and the quality was confirmed by electrophoresis. The cDNA was diluted $1 / 10$ with distilled water and $10 \mu \mathrm{l}$ was used for amplification. The RT-qPCR was performed using a real-time quantitative PCR machine (Roche Molecular Diagnostics, Pleasanton, CA, USA) with QuantiNova SYBR Green RT-PCR Kit (Qiagen Sciences, Inc., Gaithersburg, MD, USA) according to the manufacturer's protocol. Forward and reverse primers were synthesized by Invitrogen (Thermo
Fisher Scientific, Inc.) and their sequences were as follows: RANKL, forward 5'-GCAGAGAAAGCGATGGTGGA-3' and reverse 5'-GGAACCAGATGGGATGTCGG-3'; VEGF, forward 5'-TGCATTCACATTGTGCTGCTGTAG-3' and reverse 5'-GCAGATTATGCGGATCAAACC-3'; M-CSF forward 5'-ACCACCTATGCGGATTTCAT-3' and reverse 5'-TCATTACGCAGGCACAAAAG-3'; intercellular adhesion molecule 1 (ICAM-1), forward 5'-TGCTGAACTGAA GTACACTGGCATTGGTTTTG-3' and reverse 5'-CCTGAA CTGAAGTACTGGCATTGGTCAGTCA-3'; platelet-derived endothelial cell growth factor (PD-ECGF), forward 5'-AGA ACCCGAGGAATGGCGA-3' and reverse 5'-AGGCCTTTG CCACTGCTTGTA-3'; and $\beta$-actin, forward 5'-CGGAGTCAA CGGATTTGGTC-3' and reverse 5'-AGCCTTCTCCATGGT CGTGA-3'. The thermo cycling conditions of PCR were as follows: A preliminary denaturation at $94^{\circ} \mathrm{C}$ for $2 \mathrm{~min}$, followed by 40 cycles of $95^{\circ} \mathrm{C}$ for $30 \mathrm{sec}$. The annealing temperature was then reduced to $58^{\circ} \mathrm{C}$ for $30 \mathrm{sec}$ and $72^{\circ} \mathrm{C}$ for $300 \mathrm{sec}$. The reaction total reaction volume was $20 \mu \mathrm{l}$ and contained 50 ng genomic cDNA, $200 \mu \mathrm{M}$ dNTPs, $200 \mu \mathrm{M}$ primers and Taq DNA polymerase and SYBR-Green (both $2.5 \mathrm{U}$; Thermo Fisher Scientific, Inc.). Relative mRNA expression changes were quantified using the $2^{-\Delta \Delta \mathrm{Cq}}$ method (41). The results are presented as the $n$-fold change compared with $\beta$-actin.

Pain-associated behavior tests. During treatments the mechanical allodynia test and spontaneous lifting behaviors were used to evaluate the paw withdrawal mechanical threshold (PWMT). These tests were performed as previously described (42).

Western blot analysis. Synovial cells were treated with PBS, DEX or rBMP-2/Fc, homogenized in a lysate buffer (radio immunoprecipitation assay buffer) containing protease inhibitor (Sigma-Aldrich; Merck KGaA) and centrifuged at $6,000 \mathrm{x} \mathrm{g}$ at $4^{\circ} \mathrm{C}$ for $10 \mathrm{~min}$. The supernatant was used to analyze the expression levels of specific proteins. Protein concentration was measured with a BCA protein assay kit (Thermo Fisher Scientific, Inc.). A total of $10 \mu \mathrm{g} /$ lane protein was separated in $15 \%$ SDS gel and then transferred onto poly vinylidene fluoride membranes (EMD Millipore, Billierica, MA, USA). Prior to western blot analysis the membranes were blocked with $5 \%$ skimmed milk for $1 \mathrm{~h}$ at $37^{\circ} \mathrm{C}$ and subsequently incubated at $4^{\circ} \mathrm{C}$ overnight with rabbit anti-mouse primary antibodies sourced from Sigma-Aldrich (Merck KGaA) directed against: NF- $\kappa$ B (cat. no. SAB4501987), p65 (cat. no. SAB4502615), inhibitor of NF- $\kappa$ B kinase- $\beta$ (IKK- $\beta$; cat. no. SAB1300467) and NF- $\mathrm{NB}$ inhibitor- $\alpha$ (I $\kappa \mathrm{B} \alpha$; cat. no. SAB4501997). The following antibodies sourced from Abcam (Cambridge, UK) were also utilized: ALP (cat. no. ab83259), Runx2 (cat. no. ab23981), Osterix (cat. no. ab22552), Osterocalcir (cat. no. ab93876), pSmad-1 (cat. no. ab71720), pSmad-5 (cat. no. ab11437), pSmad-8 (cat. no. ab110288) and $\beta$-actin (cat. no. ab8227). All antibodies were diluted at 1:1,000. The membranes were then incubated with goat anti-rabbit horseradish peroxidase-labeled immunoglobulin G secondary antibodies (1:2,000; cat. no. PV-6001; OriGene Technologies, Inc., Beijing, China) for $24 \mathrm{~h}$ at $4^{\circ} \mathrm{C}$. The results were visualized using a chemiluminescence detection system (Roche Diagnostics, Basel, Switzerland) and with 
BandScan 5.0 software (Glyko, Inc.; BioMarin Pharmaceutical Inc., Novato, CA, USA).

Histopathological analysis. Mice were sacrificed under pentobarbital anesthesia on day 32 and their hips joints were separated and fixed with $10 \%$ formalin for $30 \mathrm{~min}$ at $37^{\circ} \mathrm{C}$. The joints were subsequently decalcified and embedded in paraffin. Sections of hip joints $(5 \mu \mathrm{m})$ from the experimental mice were stained with hematoxylin and eosin for $1 \mathrm{~h}$ at $37^{\circ} \mathrm{C}$ and the sections were used to evaluate the therapeutic effects of rBMP-2/Fc, DEX and PBS in an SI-OTFD mouse model. Tissue sections were observed using a light microscope (Olympus Corporation, Tokyo, Japan) at a magnification of $\mathrm{x} 40$. The severity of the arthritis in the joints was scored on a scale of 0-5 as previously described (43).

Vascular density measurements and evaluation of bone reabsorption activity. The vascular density measurements and an evaluation of the bone reabsorption activity of mice following treatment with $\mathrm{rBMP}-2 / \mathrm{Fc}$, DEX and PBS $(n=6)$ were conducted as previously described $(44,45)$. Briefly, for the vascular density, factor VIII-associated antigen-stained images were captured at a magnification of x200 using an ECLIPSE E600 microscope with a 20x objective lens (Nikon Corporation, Tokyo, Japan). Two images were randomly selected and the most highly vascularized area of the femoral head was recorded. The area of one image was $0.330 \mathrm{~mm}^{2}$. The vascular densities were analyzed using an image analysis system (analysis; Soft Imaging System GmbH, Munster, Germany). The vascular density was calculated as follows: (Factor VIII stained vascular area/total image area in x200 magnification) x100. For bone reabsorption activity, the cluster of differentiation 68-positive multinucleated cells containing three or more nuclei were counted in five random high-power fields (magnification, x400) in each femoral head. The area of one high-power field was $0.238 \mathrm{~mm}^{2}$. The total area analyzed per case was $1.188 \mathrm{~mm}^{2}$. A total of 6 randomly selected mice from each group were evaluated.

Half-life assays. The half-life of BMP-2 and rBMP-2/Fc were assessed via half-life experiments as described previously (46). Briefly, BMP-2 or rBMP-2were labeled with IRDye 800CW NHS Ester (LI-COR Biosciences, Lincoln, NE, USA) and the degree of labeling was determined according to the manufacturer's protocol. A total of $50 \mu \mathrm{g}$ labeled BMP-2 or rBMP-2 was injected retro-orbitally into the $\mathrm{C} 57 \mathrm{BL} / 6 \mathrm{~J}$ mice and blood was harvested from the tail every $60 \mathrm{~min}$ and collected in heparin coated tubes. The tubes were protected from light and kept at $4^{\circ} \mathrm{C}$ until blood collection was complete. Infrared luminescence was measured using the Odyssey Infrared Imaging system (LI-COR Biosciences) and analyzed using ImageJ software version 1.2 (National Institutes of Health, Bethesda, MD, USA).

Statistical analysis. All data are presented as the mean + standard deviation of three independent experiments. Unpaired data was determined using Student's t-test and comparisons between multiple groups were made using one-way analysis of variance followed by a post-hoc Tukey's test. Kaplan-Meier was used to estimate the survival rate during the 120-day long-term treatment. $\mathrm{P}<0.05$ was considered to indicate a statistically significant difference.

\section{Results}

In vitro effects of $\mathrm{rBMP}-2 / \mathrm{Fc}$ on synovial cells from a SI-OTFD mouse model. To investigate the efficacy of rBMP-2/Fc on SI-OTFD, the levels of BMP-2 and BMP-2R in synovial cells were measured. BMP-2 expression levels were significantly lower in synovial cells from the mouse model of SI-OTFD compared with the healthy mice group (Fig. 1A), whereas BMP-2R was significantly increased in the SI-OTFD group compared with the healthy group (Fig. 1B). The effect of $\mathrm{rBMP}-2 / \mathrm{Fc}$ on the expression of IL-6, IL-10, VEGF and $\mathrm{M}-\mathrm{CSF}$ in synovial cells was investigated; DEX was used as a control. The expression of IL-6, IL-10, VEGF and M-CSF were significantly upregulated in $\mathrm{rBMP}-2 / \mathrm{Fc}$-treated synovial cells compared with the control and DEX groups (Fig. 1C-F, respectively). Conversely the expression of RANKL was significantly decreased following treatment with $\mathrm{rBMP}-2 / \mathrm{Fc}$ compared with the control and DEX groups (Fig. 1G). It was also observed that the half-life of rBMP-2/Fc was significantly increased compared with BMP-2 (Fig. 1H) and rBMP-2/Fc presented a higher affinity for BMP-2 (Fig. 1I). These results suggest that rBMP-2/Fc effectively binds with BMP-2R and that $\mathrm{BBMP}-2 / \mathrm{Fc}$ treatment may regulate the expression of IL-6, IL-10, M-CSF and RANKL in synovial cells.

Analysis of the underlying mechanism of the rBMP-2/Fc-mediated signaling pathway for osteonecrosis of the femoral head in a mouse model. Although the benefits of BMP-2 on arthritis have been previously investigated (21), the underlying mechanism of the rBMP-2/Fc-mediated signaling pathway for osteonecrosis of the femoral head in a mouse model remains unknown. It was observed that the expression of BMP-2 was positively associated with the gene signatures of $N F-\kappa B$ signaling, indicating that the NF- $\kappa B$ signaling pathway may be regulated by BMP-2 in bone synovial cells (Fig. 2A). NF- $\kappa \mathrm{B}$ was detected at significantly higher levels in the $\mathrm{rBMP}-2 / \mathrm{Fc}$ group compared with the control and BMP-2R groups. It was also observed that treatment with rBMP-2/Fc significantly increased the cell viability of synovial cells compared with the BMP-2 and control groups (Fig. 2B). The cell growth rate was also significantly increased in the rBMP-2/Fc group at 48 and $72 \mathrm{~h}$ compared with the DEX and control groups (Fig. 2C). Treatment with rBMP-2/Fc significantly decreased the apoptosis of synovial cells induced by steroids compared with the DEX and control groups (Fig. 2D). Western blot analysis revealed that the addition of BMP-2R resulted in a marked decrease in $\mathrm{NF}-\kappa \mathrm{B}$ protein expression, whereas treatment with $\mathrm{rBMP}-2 / \mathrm{Fc}$ markedly increased $\mathrm{NF}-\kappa \mathrm{B}$ protein expression levels in vitro (Fig. $2 \mathrm{E}$ ). Furthermore, the protein expression levels of $\mathrm{p} 65$, IKK $\beta$ and $\mathrm{I} \kappa \mathrm{B} \alpha$ were markedly increased in synovial cells treated with $\mathrm{rBMP}-2 / \mathrm{Fc}$, whereas they were notably downregulated following treatment with BMP-2R (Fig. 2F). In vitro western blot analysis revealed that alkaline phosphatase (ALP), runt-related transcription factor 2 (Runx2), osterix and osteocalcin were significantly upregulated in rBMP-2/Fc-treated synoviocytes compared with the control and BMP-2R groups (Fig 2G). Additionally, 

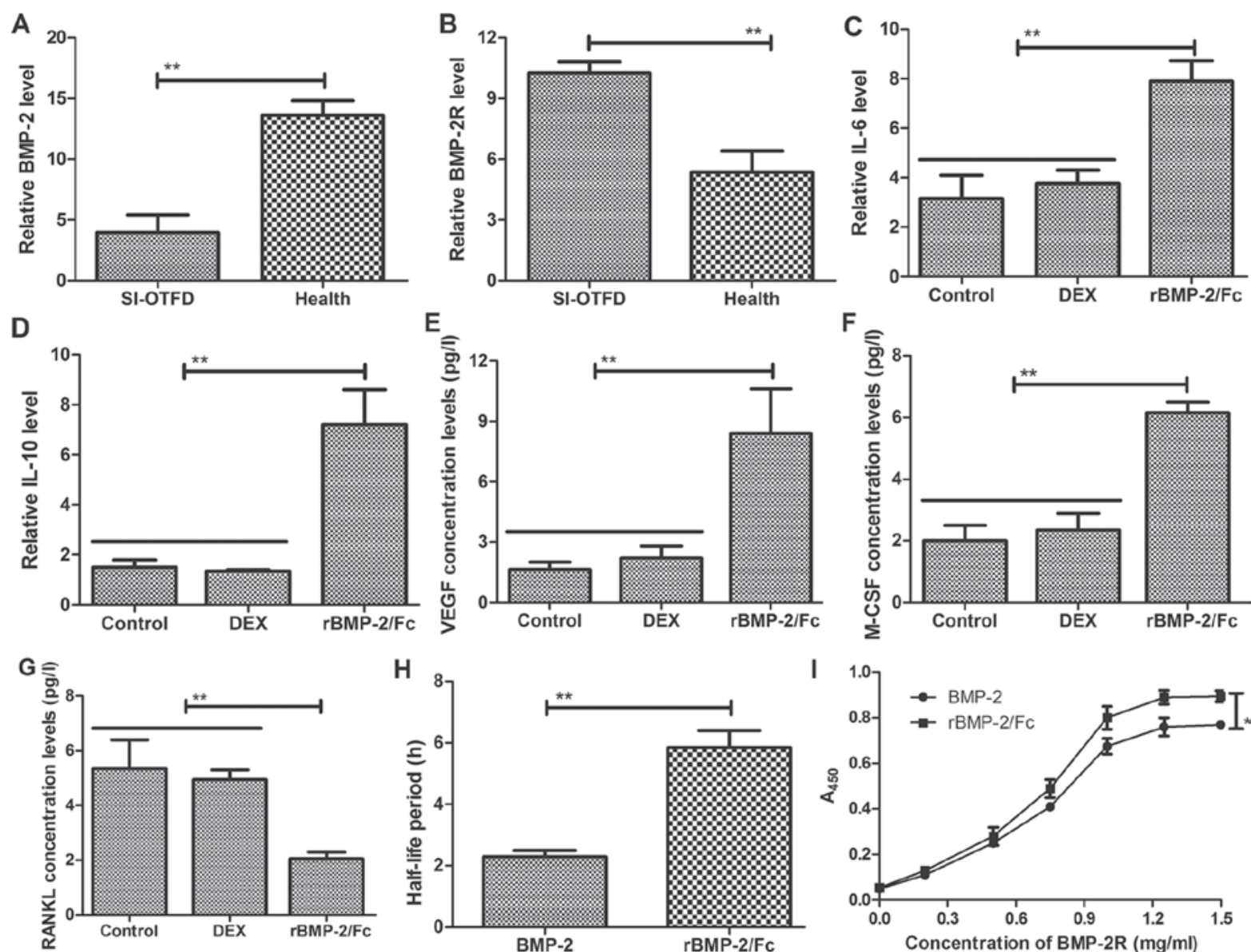

Figure 1. Effects of $\mathrm{rBMP}-2 / \mathrm{Fc}$ on synovial cells isolated from experimental mice. The expression of (A) BMP-2 and (B) BMP-2R in synovial cells from a mouse model of osteonecrosis of the femoral head were determined by ELISA. The expression of (C) IL-6 (D) IL-10, (E) VEGF, (F) M-CSF and (G) RANKL in synovial cells were analyzed by ELISA. (H) The half-life periods of rBMP-2/Fc and BMP-2 were determined by pharmacokinetic methods. (I) The affinity of rBMP-2/Fc for BMP-2R was measured. ${ }^{*} \mathrm{P}<0.05,{ }^{* *} \mathrm{P}<0.01$. BMP-2, bone morphogenetic protein-2; rBMP, recombinant bone morphogenetic protein; Fc, Fc fragment; BMP-2R, bone morphogenetic protein-2 receptor; Il, interleukin; VEGF; vascular endothelial growth factor; M-CSF, macrophage colony-stimulating factor; RANKL, receptor activator of NF- $\mathrm{kB}$ ligand; SI-OTFD, steroid-induced osteonecrosis of the femoral head; DEX, dexamethasone.

treatment with $\mathrm{rBMP}-2 / \mathrm{Fc}$ induced a significant increase in the protein levels of phosphorylated Smad-1, Smad-5 and Smad-8 in Saos-2 cells (Fig. 2H). These results indicate that rBMP-2/Fc exerts a beneficial effect by increasing the viability of synovial cells obtained from experimental mice.

Therapeutic effects of $r B M P-2 / F c$ for steroid-induce osteonecrosis of the femoral head mice. Experimental SI-OTFD mice were administered with $\mathrm{rBMP}-2 / \mathrm{Fc}, \mathrm{DEX}$ or PBS as described above. The therapeutic effects of these agents were recorded every 3 days using an arthritic score in each experimental group. It was revealed that treatment with $\mathrm{rBMP}-2 / \mathrm{Fc}$ significantly ameliorated the clinical symptoms used to measure an arthritic score compared with the DEX- and PBS-treated mice (Fig. 3A). Additionally, rBMP-2/Fc-treated mice exhibited a significantly decreased PWMT compared with the DEX and PBS groups (Fig. 3B). Furthermore, the VEGF, BMP-2R, RANKL and M-CSF mRNA expression levels were measured in the synovial cells from mice in each treatment group. The expression levels of BMP-2R and RANKL were significantly downregulated in $\mathrm{rBMP}-2 / \mathrm{Fc}$-treated mice compared with the DEX and PBS groups (Fig. 3C and D). Conversely, the expression levels of VEGF and M-CSF were significantly upregulated in mice treated with $\mathrm{rBMP}-2 / \mathrm{Fc}$ compared with the DEX and PBS groups (Fig. 3E and F). These results suggest that rBMP-2/Fc was able to improve the clinical symptoms and arthritis-associated factors in mice with osteonecrosis of the femoral head, which may contribute to the recovery of mice from osteonecrosis of the femoral head.

Vascular density measurements, evaluation of bone reabsorption activity and histological evaluation of femoral head mice treated by $r B M P-2 / F c$. Throughout the experimental period the body and spleen weights of the mice were measured. These results revealed that at day 30 the body weights of the rBMP-2/Fc-treated mice were significantly increased compared with the DEX and PBS groups (Fig. 4A and B). The DEX group was also significantly heavier than the PBS group at day 30 . The notable changes in body weight appeared to begin at day 9 . The spleen weight was also significantly reduced in the rBMP-2/Fc group compared with the PBS and DEX groups. The vascular density and bone reabsorption activity of the ischemic femoral head in the rBMP-2/Fc-treated group were significantly higher compared with the DEX and PBS groups (Fig. 4C and D). Furthermore, histological analysis revealed that $\mathrm{rBMP}-2 / \mathrm{Fc}$-treated mice exhibited homogeneous density and presented with notably smooth and regular articular surface (Fig. 4E). It was also identified that 

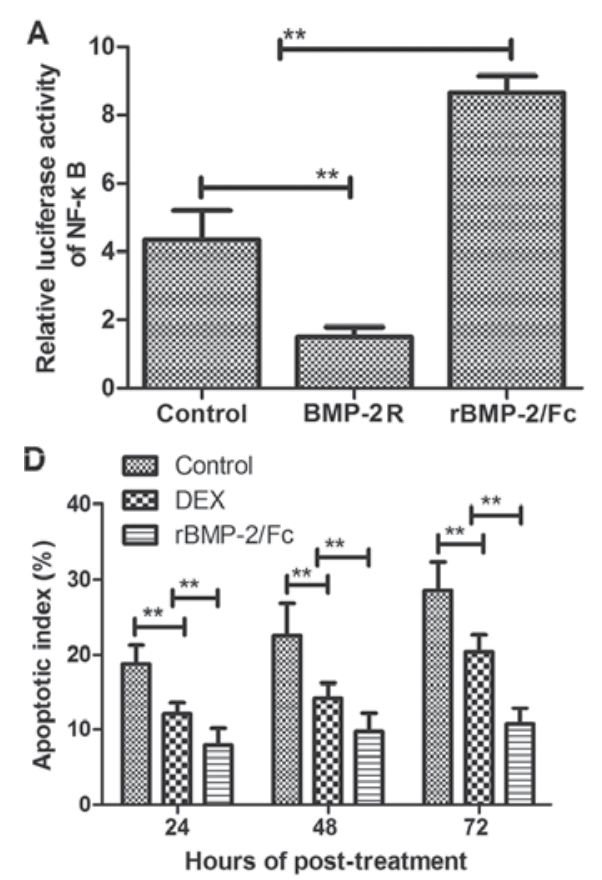

G

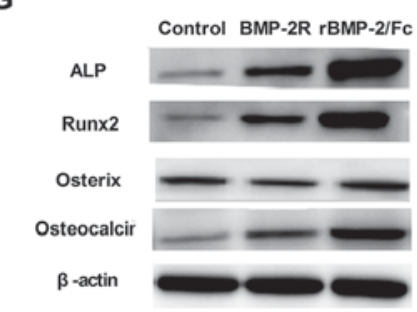

B

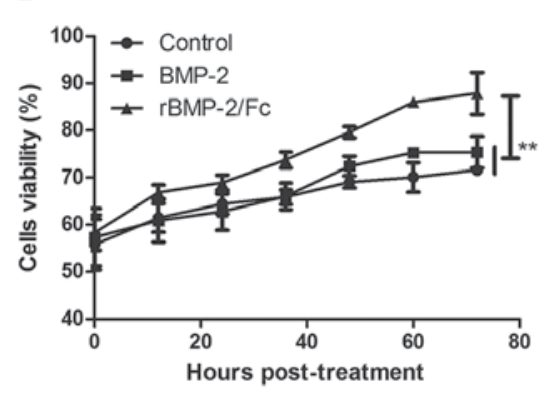

E

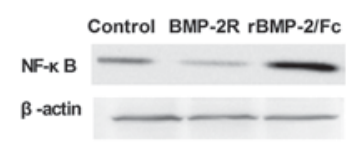

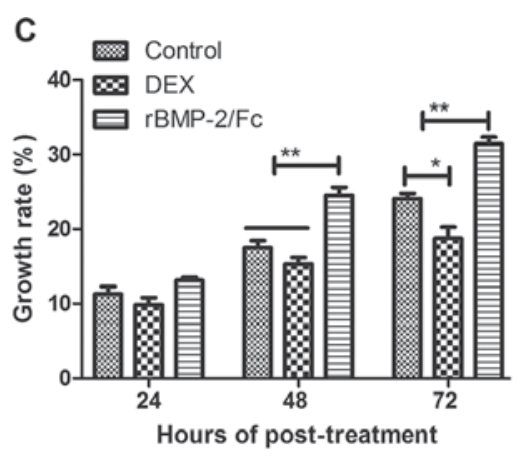

$\mathbf{F}$

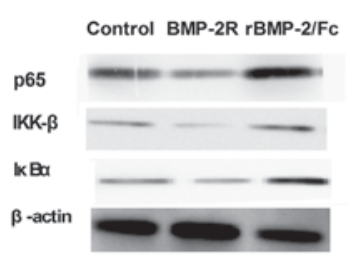

H

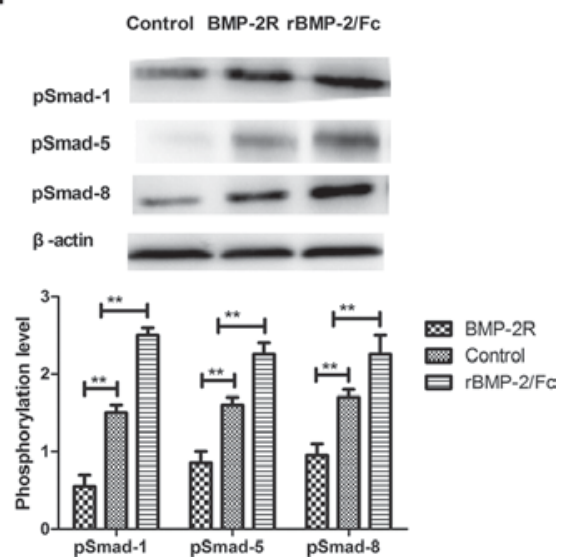

Figure 2. Analysis of the signaling pathways mediated by rBMP-2/Fc in synovial cells. (A) Analysis of the association between BMP-2 and NF- $\mathrm{kB}$ expression in synovial cells as determined by luciferase activity. (B) The viability of synovial cells following incubation with $\mathrm{rBMP}-2 / \mathrm{Fc}(10 \mathrm{mg} / \mathrm{ml}), \mathrm{BMP}-2$ (2 mg/ml) or PBS for different time periods as determined by the refractive index. (C) The growth rate of synovial cells following treatment with PBS, DEX or $\mathrm{rBMP}-2 / \mathrm{Fc}$ for 24, 48 and 72 has determined by an MTT assay. (D) The effects of rBMP-2/Fc on the apoptosis of synovial cells as determined by flow cytometry. Western

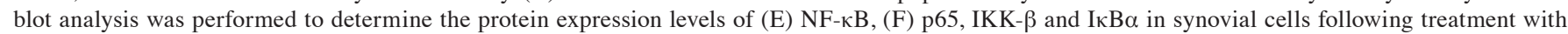
BMP-2R or rBMP-2/Fc. The protein expression of (G) ALP, Runx2, osterix and osteocalcin, and (H) pSmad-1, pSmad-5 and pSmad-8 in Saos-2 cells was determined via western blot analysis. ${ }^{*} \mathrm{P}<0.05,{ }^{* *} \mathrm{P}<0.01$. BMP-2, bone morphogenetic protein-2; rBMP, recombinant bone morphogenetic protein; $\mathrm{Fc}, \mathrm{Fc}$

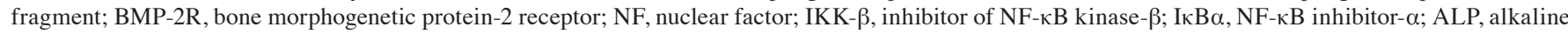
phosphatase; Runx2, runt-related transcription factor 2; p, phosphorylated; DEX, dexamethasone.

a well-preserved secondary ossification center and trabecular bone formation was greater (Fig. 4F) than the DEX-treated group and PBS-treated group.

The results indicated that the articular cartilage of mice treated by $\mathrm{rBMP}-2 / \mathrm{Fc}$ were more healthier. It was also observed that the angiogenesis factors ICAM-1 and PD-ECGF were significantly upregulated following $\mathrm{rBMP}-2 / \mathrm{Fc}$ treatment in synovial cells compared with the PBS and DEX groups (Fig. 4G and H). These results suggest that rBMP-2/Fc treatment markedly improves pathological status of femoral head analyzed by histological staining.

\section{Discussion}

Osteonecrosis of the femoral head is a serious arthritic disease that undergoes complex pathological processes during its initiation and development (47). Previous studies have demonstrated that core decompression combined with BMPs, growth factors, bone grafting or stem cells are therapeutic options for osteonecrosis of the femoral head (48-50). The symptoms of osteonecrosis of the femoral head are multitudinous and include pain, stiff joints with limited activity, lameness, different degrees of femoral head necrosis $(5,51)$. In recent years the incidence rate of osteonecrosis of the femoral head has increased $(52,53)$. Therefore, further treatment options are required to improve the prognosis and comfort of patients diagnosed with osteonecrosis of the femoral head. In the present study, the therapeutic effects of BMP-2/Fc in a mouse model of osteonecrosis of the femoral head were investigated with DEX used as a positive control. The results of the present study suggested that BMP-2/Fc is an effective agent for the treatment of osteonecrosis of the femoral head.

BMPs are members of the transforming growth factor- $\beta$ superfamily, which regulates cellular metabolism and signaling 
A

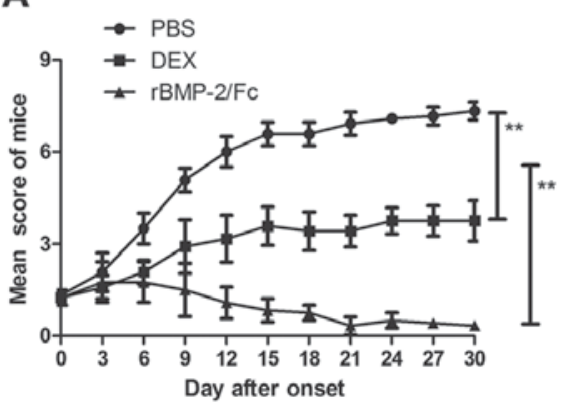

D

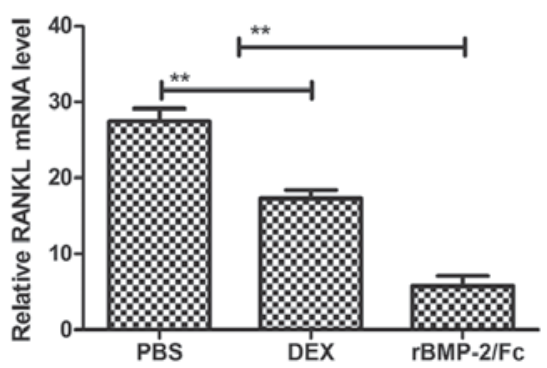

B

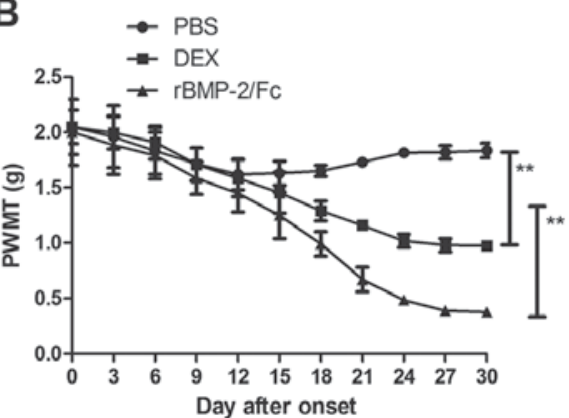

E

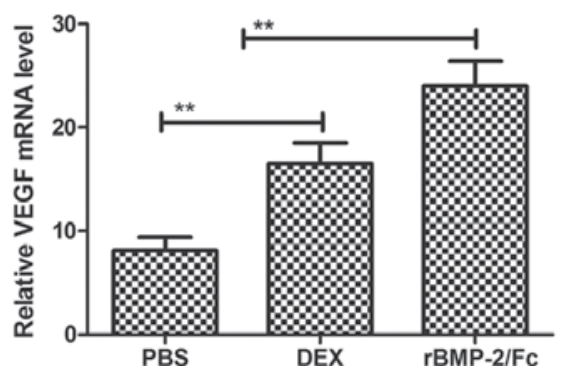

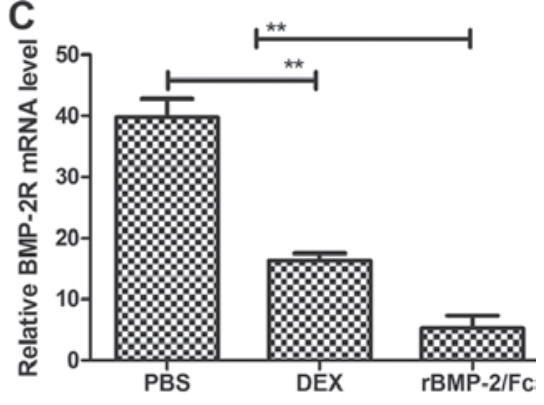

$\mathbf{F}$

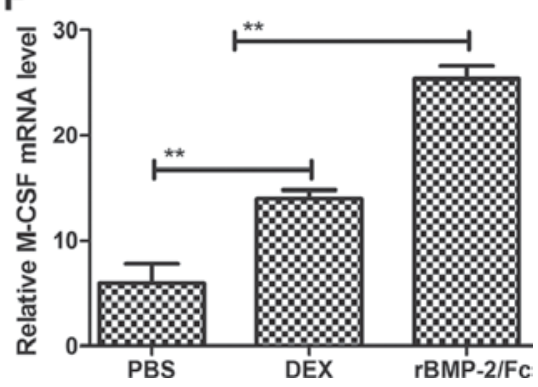

Figure 3. In vivo effects of $\mathrm{rBMP}-2 / \mathrm{Fc}$ on steroid-induced osteonecrosis of the femoral head in a mouse model. (A) The clinical symptoms of mice with steroid-induced osteonecrosis of the femoral head were used to determine an arthritic score. (B) Pain-associated behaviors of experimental mice following treatment with PBS, DEX or rBMP-2/Fc were determined by PWMT. The mRNA expression levels of (C) BMP-2R, (D) RANKL, (E) VEGF and (F) M-CSF in experimental mice with steroid-induced osteonecrosis of the femoral head were determined by reverse transcription-quantitative polymerase chain reaction." $\mathrm{P}<0.01$. BMP-2, bone morphogenetic protein-2; rBMP, recombinant bone morphogenetic protein; Fc, Fc fragment; DEX, dexamethasone; PWMT, paw withdrawal mechanical threshold; BMP-2R, bone morphogenetic protein-2 receptor; VEGF; vascular endothelial growth factor; M-CSF, macrophage colony-stimulating factor; RANKL, receptor activator of NF-kB ligand.

pathways, including cell proliferation, migration, apoptosis, differentiation and adhesion in many types of cells $(54,55)$. Recent studies have reported that BMP-2 may be used to reconstruct segmental mandibular defects and repair ischemic damage by inducing angiogenesis and osteogenesis, and by decreasing osteoclast bone reabsorption activity $(56,57)$. However, the half-life of BMP-2 is short in vivo, which limits its clinical application $(58,59)$. In the present study, a recombinant BMP-2 linked with an Fc fragment, rBMP-2/Fc, was synthesized to prolong its half-life in vivo. The longer half-life of $\mathrm{rBMP}-2 / \mathrm{Fc}$ significantly improved the viability of synoviocytes compared with BMP-2. The results indicated that $\mathrm{rBMP}-2 / \mathrm{Fc}$ is an efficient drug for the inhibition of joint inflammation and damage. The effect of $\mathrm{rBMP}-2 / \mathrm{Fc}$ was investigated according to its clinical presentation.

The femoral head is a highly vascularized articular tissue and angiogenesis is crucial to prevent the progression of osteonecrosis of the femoral head $(60,61)$. Neovascularization supports the osteoblasts and mesenchymal stem cells during femoral head repair and construction $(62,63)$. However, the mRNA levels of BMP-2R were significantly higher in SI-OTFD mice compared with the healthy mice, suggesting that they may have been downregulated by $\mathrm{rBMP}-2 / \mathrm{Fc}$ treatment. A recent study has summarized the different treatments available for osteonecrosis of the femoral head and the different mechanisms by which they act on osteogenesis and angiogenesis has also been discussed in association with bone regeneration (15). All treatment strategies emphasize the importance of angiogenesis for bone regeneration. In addition, osteonecrosis of the femoral head causes a reduction in vascular density, which leads to an inadequate amount of subchondral bone at the femoral head, which results in osteocyte death and the collapse of the articular surface (15). A previous study has indicated that revascularization contributes to the recovery of osteonecrosis at the femoral head, which suggests that it may be part of the underlying mechanism of initiation, development and aggravation of glucocorticoid-induced osteonecrosis of the femoral head (64). VEGF and M-CSF serve an essential role in angiogenesis and bone regeneration $(23,65)$. The present study investigated angiogenesis and synovial repair in a mouse model of osteonecrosis of the femoral head following treatment with $\mathrm{rBMP}-2 / \mathrm{Fc}$. In vivo experiments indicated that $\mathrm{rBMP}-2 / \mathrm{Fc}$ significantly increased VEGF and M-CSF in synovial cells and contributed to the improvement of the clinical features of angiogenesis and osteogenesis.

Inflammatory cytokines have been identified as crucial regulatory signaling networks in osteonecrosis of the femoral head, which are mediated by intracellular kinase signaling pathways and regulate recruitment, stimulation, activation and the accumulation of autoimmune cells (66). The causes of osteonecrosis of the femoral head are not fully understood, however, laboratory and clinical evidence suggest that inflammatory cytokines may contribute to its pathogenesis $(67,68)$. Therefore, blocking the inflammatory cytokine pathways may interrupt the inflammatory process and break the cycle of inflammation, thereby limiting joint damage $(69,70)$. In the present study, the expression levels of inflammatory factors following $\mathrm{rBMP}-2 / \mathrm{Fc}$ treatment were measured. The results revealed that the administration of $\mathrm{rBMP}-2 / \mathrm{Fc}$ significantly reduced the pathogenesis of osteonecrosis of the femoral head by inhibiting the inflammatory cytokines (IL-6 and IL-10). 

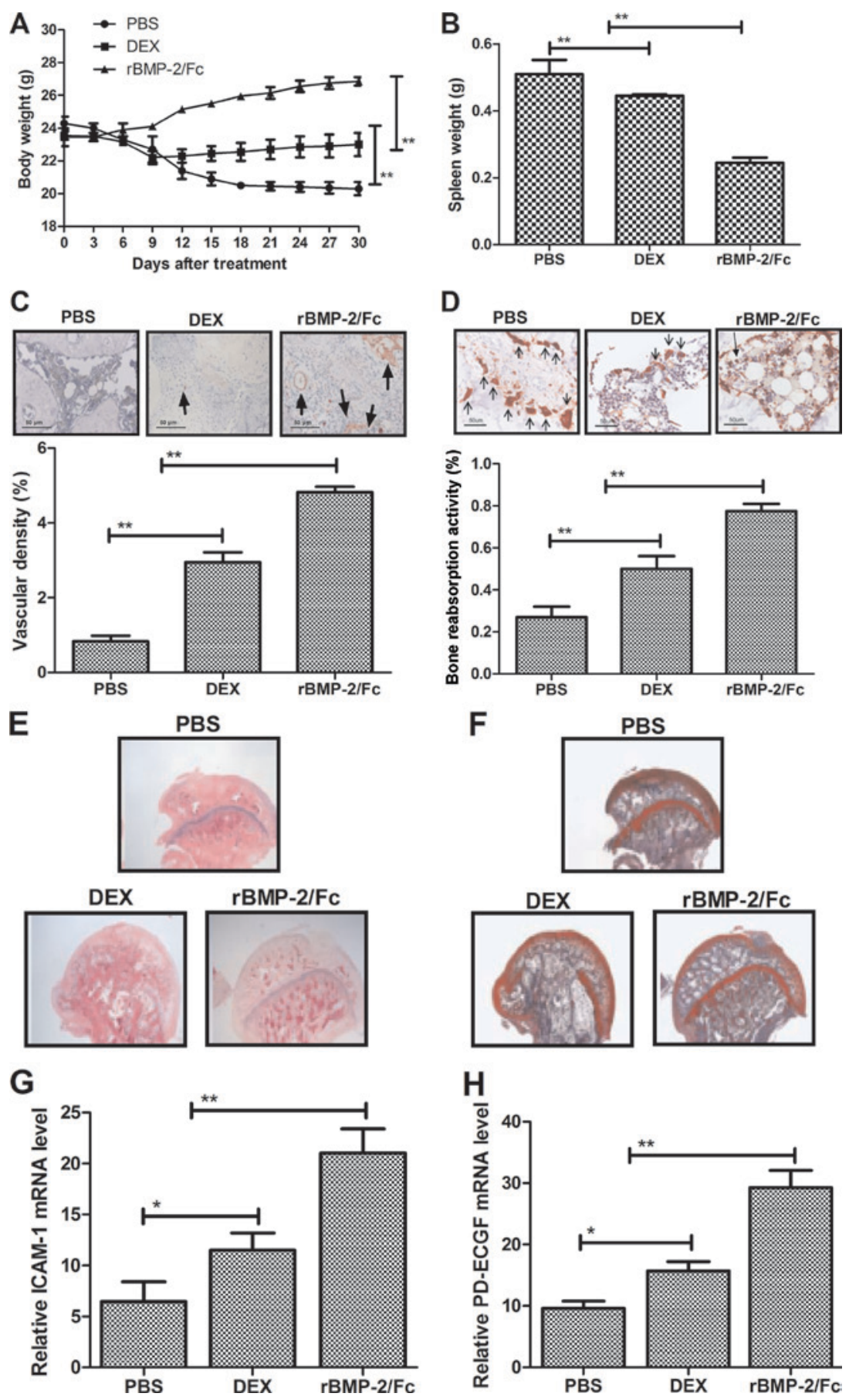

Figure 4. Histopathologic analysis of the therapeutic effects of rBMP-2/Fc in steroid-induced osteonecrosis of the femoral head in a mouse model. (A) Analysis of the (A) body weights and (B) spleen weights of mice following 30-days treatment with PBS, DEX or rBMP-2/Fc. (C) The vascular density of the femoral head in mice treated with PBS, DEX or rBMP-2/Fc was determined via Factor VIII staining of the vascular area. (D) Evaluation of bone reabsorption activity of the ischemic femoral head in mice treated with PBS, DEX or rBMP-2/Fc as determined by cluster of differentiation 68 staining. (E) Images of the smooth articular surface and (F) the well-preserved secondary ossification center in mice treated with PBS, DEX or rBMP-2/Fc were used to determine histopathologic analysis. Magnification, 40x. The mRNA expression of the angiogenesis factors (G) ICAM-1 and (H) PD-ECGF in synovial cells in experimental mice as determined by reverse transcription-quantitative polymerase chain reaction. $\mathrm{P}<0.05$; ${ }^{* *} \mathrm{P}<0.01$. BMP-2, bone morphogenetic protein-2; rBMP, recombinant bone morphogenetic protein; Fc, Fc fragment; DEX, dexamethasone; ICAM-1, intercellular adhesion molecule 1; PD-ECGF, platelet-derived endothelial cell growth factor.

A previous study has demonstrated that the NF- $\kappa \mathrm{B}$ signaling pathway serves an essential role in controlling revascularization and osteogenesis by regulating VEGF, BMP-2, RANKL and M-CSF expression during the progression of glucocorticoid-induced osteonecrosis of the femoral head (71). In the present study, the underlying mechanism of the rBMP-2/Fc-mediated signaling pathway in the progression of glucocorticoid-induced osteonecrosis of the femoral head was investigated. It was revealed that $\mathrm{rBMP}-2 / \mathrm{Fc}-$ mediated improvement may be attributed to the upregulation of the NF- $\kappa \mathrm{B}$ signaling pathway, which promotes revascularization and osteogenesis in the femoral head.

In conclusion, the present study investigated the roles of $\mathrm{rBMP}-2 / \mathrm{Fc}$ in association with the level of cytokines present 
in the joint, homeostasis, revascularization and osteogenesis. The results demonstrated that $\mathrm{rBMP}-2 / \mathrm{Fc}$ is beneficial for the treatment of osteonecrosis of the femoral head by promoting the expression of proangiogenic factors in synovial cells. This leads to revascularization and osteogenesis through regulation of the $N F-\kappa B$ signaling pathway. These findings also indicate that $\mathrm{rBMP}-2 / \mathrm{Fc}$ treatment presents beneficial effects on alleviating joint inflammation, cartilage destruction and bone damage in mice with osteonecrosis of the femoral head, suggesting that $\mathrm{rBMP}-2 / \mathrm{Fc}$ may be a potential novel agent for the treatment of osteonecrosis of the femoral head in humans, although further investigation is required to confirm this.

\section{Acknowledgements}

Not applicable.

\section{Funding}

No funding was received.

\section{Availability of data and materials}

The analyzed data sets generated during the present study are available from the corresponding author on reasonable request.

\section{Authors' contributions}

DZ designed the study and wrote the manuscript. CW and $\mathrm{HZ}$ performed the research and $\mathrm{HZ}$ analyzed the data. All authors have read and approved this manuscript.

\section{Ethics approval and consent to participate}

All animal procedures were reviewed and approved by the Ethical Committee of Tianjin Medical University (Tianjin, China; certificate no. TJMWD-2012011B) and the China Experimental Animal Protection Association. All efforts were made to minimize the suffering of the experimental mice.

\section{Consent for publication}

Not applicable.

\section{Competing interests}

All authors have no conflict of interest to declare.

\section{References}

1. Onuora S: Osteoarthritis: Molecular imaging detects activated macrophages. Nat Rev Rheumatol 12: 313, 2016.

2. Shepherd J, Cooper K, Harris P, Picot J and Rose M: The clinical effectiveness and cost-effectiveness of abatacept, adalimumab, etanercept and tocilizumab for treating juvenile idiopathic arthritis: A systematic review and economic evaluation. Health Technol Assess 20: 1-222, 2016.

3. Bhadu D, Das SK, Dhakad U, Sharma M, Srivastava D and Tripathy SR: Synovial chondromatosis involving multiple joints in rheumatoid arthritis: A case report review of the literature. Int J Rheum Dis 20: 2148-2151, 2017.
4. Ma YW, Jiang DL, Zhang D, Wang XB and Yu XT: Radial extracorporeal shock wave therapy in a person with advanced osteonecrosis of the femoral head: A case report. Am J Phys Med Rehabil 95: e133-e139, 2016.

5. Lee GW, Park KS, Kim DY, Lee YM, Eshnazarov KE and Yoon TR: Results of total hip arthroplasty after core decompression with tantalum rod for osteonecrosis of the femoral head. Clin Orthop Surg 8: 38-44, 2016.

6. Zhu HY, Gao YC, Wang Y and Zhang CQ: Circulating exosome levels in the diagnosis of steroid-induced osteonecrosis of the femoral head. Bone Joint Res 5: 276-279, 2016.

7. Kuroda Y, So K, Goto K and Matsuda S: Extremely early stage osteonecrosis of the femoral head in a patient with hip pain secondary systemic steroid pulse therapy for Vogt-Koyanagi-Harada syndrome: A case report. Int J Surg Case Rep 25: 97-101, 2016.

8. Cabrolier J and Molina M: Is instillation of bone marrow stem cells at the time of core decompression useful for osteonecrosis of the femoral head? Medwave 16 (Suppl 1): e6406, 2016 (In Spanish).

9. Farzaei MH, Farzaei F, Abdollahi M, Abbasabadi Z, Abdolghaffari AH and Mehraban B: A mechanistic review on medicinal plants used for rheumatoid arthritis in traditional Persian medicine. J Pharm Pharmacol 68: 1233-11248, 2016.

10. Rajeev A, Choudhry N, Shaikh M and Newby M: Lumbar facet joint septic arthritis presenting atypically as acute abdomen-A case report and review of the literature. Int J Sur Case Rep 25: 243-245, 2016.

11. Meyers MH: Osteonecrosis of the femoral head. Pathogenesis and long-term results of treatment. Clin Orthop Relat Res: 51-61, 1988.

12. Gold EW and Cangemi PJ: Incidence and pathogenesis of alcohol-induced osteonecrosis of the femoral head. Clin Orthop Relat Res: 222-226, 1979.

13. Vignon G and Meunier P: Pathogenesis of primary osteonecrosis of the femoral head. Hypothesis of the subchondral fatigue fracture. Nouv Presse Med 2: 1751-1753, 1973.

14. Yamamoto T and Iwamoto Y: Corticosteroids treatments and osteonecrosis of the femoral head. Fukuoka Igaku Zasshi 106: 47-53, 2015 (In Japanese).

15. Wang C, Peng J and Lu S: Summary of the various treatments for osteonecrosis of the femoral head by mechanism: A review. Exp Ther Med 8: 700-706, 2014.

16. Pelaz A, Junquera L, Gallego L, Garcia-Consuegra L, Junquera S and Gomez C: Alternative treatments for oral bisphosphonate-related osteonecrosis of the jaws: A pilot study comparing fibrin rich in growth factors and teriparatide. Med Oral Patol Oral Cir Bucal 19: e320-e326, 2014.

17. Meloni MC, Hoedemaeker WR and Fornasier V: Failed vascularized fibular graft in treatment of osteonecrosis of the femoral head. A histopathological analysis. Joints 4: 24-30, 2016.

18. Furuya T, Maeda S, Momohara S, Taniguchi A and Yamanaka H: Dental treatments, tooth extractions and osteonecrosis of the jaw in Japanese patients with rheumatoid arthritis: Results from the IORRA cohort study. J Bone Miner Metab 35: 344-350, 2017.

19. Sadile F, Bernasconi A, Russo S and Maffulli N: Core decompression versus other joint preserving treatments for osteonecrosis of the femoral head: A meta-analysis. Br Med Bull 118: 33-49, 2016.

20. Singh K, Massel DH, Mayo BC, Bohl DD, Long WW and Modi KD: Bone morphogenetic proteins in lumbar arthrodesis: What is all the debate about? Commentary on an article by Daniel C. Beachler, PhD, MHS, et al: 'Bone morphogenetic protein use and cancer risk among patients undergoing lumbar arthrodesis: A case-cohort study using the SEER-medicare database'. J Bone Joint Surg Am 98: e57, 2016.

21. Aruwajoye OO, Aswath PB and Kim HKW: Material properties of bone in the femoral head treated with ibandronate and BMP-2 following ischemic osteonecrosis. J Orthop Res 35: 1453-1460, 2017.

22. Rahim I, Salt S and Heliotis M: Successful long-term mandibular reconstruction and rehabilitation using non-vascularised autologous bone graft and recombinant human BMP-7 with subsequent endosseous implant in a patient with bisphosphonate-related osteonecrosis of the jaw. Br J Oral Maxillofac Surg 53: 870-874, 2015.

23. Wang W, Liu L, Dang X, Ma S, Zhang M and Wang K: The effect of core decompression on local expression of BMP-2, PPAR- $\gamma$ and bone regeneration in the steroid-induced femoral head osteonecrosis. BMC Musculoskelet Disord 13: 142, 2012. 
24. Grcevic D, Jajic Z, Kovacic N, Lukic IK, Velagic V, Grubisic F Ivcevic S and Marusic A: Peripheral blood expression profiles of bone morphogenetic proteins, tumor necrosis factor-superfamily molecules and transcription factor Runx 2 could be used as markers of the form of arthritis, disease activity and therapeutic responsiveness. J Rheumatol 37: 246-256, 2010.

25. Lories RJ and Luyten FP: Bone morphogenetic proteins in destructive and remodeling arthritis. Arthritis Res Ther 9: 207, 2007.

26. Postigo J, Iglesias M, Alvarez P, Jesús Augustin J, Buelta L, Merino J and Merino R: Bone morphogenetic protein and activin membrane-bound inhibitor, a transforming growth factor beta rheostat that controls murine treg cell/Th17 cell differentiation and the development of autoimmune arthritis by reducing interleukin-2 signaling. Arth Rheum 68: 1551-1562, 2016.

27. Brescia AC, Simonds MM, McCahan SM, Fawcett PT and Rose CD: The role of transforming growth factor $\beta$ signaling in fibroblast-like synoviocytes from patients with oligoarticular juvenile idiopathic arthritis: Dysregulation of transforming growth factor $\beta$ signaling, including overexpression of bone morphogenetic protein 4, may lead to a chondrocyte phenotype and may contribute to bony hypertrophy. Arth Rheum 66: $1352-1362,2014$.

28. Okubo Y, Bessho K, Fujimura K, Kusumoto K, Ogawa Y and Iizuka T: Osteogenesis by recombinant human bone morphogenetic protein-2 at skeletal sites. Clin Orthop Relat Res: 295-301, 2000.

29. Ozec Y, Ozturk M,Kýlýç E, Yeler H, Göze F and Gümüş C: Effect of recombinant human bone morphogenetic protein-2 on mandibular distraction osteogenesis. J Craniofac Surg 17: 80-83, 2006.

30. Marinova-Mutafchieva L, Taylor P, Funa K, Maini RN and Zvaifler NJ: Mesenchymal cells expressing bone morphogenetic protein receptors are present in the rheumatoid arthritis joint Arth rheumatism 43: 2046-2055, 2000.

31. Issa JP, do Nascimento C, Lamano T, Iyomasa MM, Sebald W and de Albuquerque RF Jr: Effect of recombinant human bone morphogenetic protein- 2 on bone formation in the acute distraction osteogenesis of rat mandibles. Clin Oral Implants Res 20 : 1286-1292, 2009.

32. Yonezawa $\mathrm{H}$, Harada $\mathrm{K}$, Ikebe $\mathrm{T}$, Shinohara $\mathrm{M}$ and Enomoto $\mathrm{S}$ Effect of recombinant human bone morphogenetic protein-2 (rhBMP-2) on bone consolidation on distraction osteogenesis: A preliminary study in rabbit mandibles. J Craniomaxillofac Surg 34: 270-276, 2006.

33. Tekari A, May RD, Frauchiger DA, Chan SC, Benneker LM and Gantenbein B: The BMP2 variant L51P restores the osteogenic differentiation of human mesenchymal stromal cells in the presence of intervertebral disc cells. Eur Cell Mater 33: 197-210, 2017

34. Zalavras CG and Lieberman JR: Osteonecrosis of the femoral head: evaluation and treatment. J Am Acad Orthop Surg 22: 455-464, 2014.

35. Greenhill CJ, Jones GW, Nowell MA, Newton Z, Harvey AK, Moideen AN, Collins FL, Bloom AC, Coll RC, Robertson AA, et al: Interleukin-10 regulates the inflammasome-driven augmentation of inflammatory arthritis and joint destruction. Arthritis Res Ther 16: 419, 2014.

36. Davey G and Wu Z: Attitudes in China toward the use of animals in laboratory research. Altern Lab Anim 35: 313-316, 2007.

37. Kim HB, Lee SW, Mun CH, Yoon JY, Pai J, Shin I, Park YB, Lee SK and Cho JW: O-linked N-acetylglucosamine glycosylation of p65 aggravated the inflammation in both fibroblast-like synoviocytes stimulated by tumor necrosis factor- $\alpha$ and mice with collagen induced arthritis. Ar Res Ther 17: 248, 2015.

38. Elsafadi M, Manikandan M, Dawud RA, Alajez NM, Hamam R, Alfayez M, Kassem M, Aldahmash A and Mahmood A: Transgelin is a TGF $\beta$-inducible gene that regulates osteoblastic and adipogenic differentiation of human skeletal stem cells through actin cytoskeleston organization. Cell Death Dis 7: e2321, 2016.

39. Figueiredo CP, Simon D, Englbrecht M, Haschka J, Kleyer A, Bayat S, Hueber A, Pereira RM, Rech J and Schett G: Quantification and impact of secondary osteoarthritis in patients with anti-citrullinated protein antibodies positive rheumatoid arthritis. Arth Rheumatol 68: 2114-2121, 2016.

40. Li H, Zhang L, Guo W and Xu D: Development of a genetically engineered Escherichia coli strain for plasmid transformation in Corynebacterium glutamicum. J Microbiol Methods 131: $156-160,2016$

41. Livak KJ and Schmittgen TD: Analysis of relative gene expression data using real-time quantitative PCR and the 2(-Delta Delta C(T)) method. Methods 25: 402-408, 2001.
42. Sun Y, Jiang M, Hou B, Lu C, Lei Y, Ma Z and Gu X: Mas-related gene (Mrg) $\mathrm{C}$ activation attenuates bone cancer pain via modulating Gi and NR2B. PLoS One 11: e0154851, 2016.

43. Bai F, Tian H, Niu Z, Liu M, Ren G, Yu Y, Sun T, Li S and Li D Chimeric anti-IL-17 full-length monoclonal antibody is a novel potential candidate for the treatment of rheumatoid arthritis. Int J Mol Med 33: 711-721, 2014.

44. Kinsella S, Murphy K, Breen M, O'Neill S, McLaughlin P, Coyle J, Bogue C, O'Neill F, Moore N, McGarrigle A, et al: Comparison of single CT scan assessment of bone mineral density, vascular calcification and fat mass with standard clinical measurements in renal transplant subjects: The ABC HeART study. BMC Nephrol 16: 188, 2015.

45. Morimoto Y, Hoshino H, Sakurai T, Terakawa S and Nagano A: Quantitative evaluation of bone resorption activity of osteoclast-like cells by measuring calcium phosphate resorbing area using incubator-facilitated and video-enhanced microscopy. Microsc Res Tech 72: 317-322, 2009.

46. Zhu EF, Gai SA, Opel CF, Kwan BH, Surana R, Mihm MC, Kauke MJ, Moynihan KD, Angelini A, Williams RT, et al: Synergistic innate and adaptive immune response to combination immunotherapy with anti-tumor antigen antibodies and extended serum half-life IL-2. Cancer Cell 27: 489-501, 2015.

47. Pierce TP, Elmallah RK, Jauregui JJ, Poola S, Mont MA and Delanois RE: A current review of non-vascularized bone grafting in osteonecrosis of the femoral head. Curr Rev Musculoskelet Med 8: 240-245, 2015

48. Pierce TP, Jauregui JJ, Elmallah RK, Lavernia CJ, Mont MA and Nace J: A current review of core decompression in the treatment of osteonecrosis of the femoral head. Curr Rev Musculoskelet Med 8: 228-232, 2015.

49. Peng WX and Wang L: Adenovirus-mediated expression of bmp-2 and BFGF in bone marrow mesenchymal stem cells combined with demineralized bone matrix for repair of femoral head osteonecrosis in beagle dogs. Cell Physiol Biochem 43: 1648-1662, 2017.

50. Shi L, Sun W, Gao F, Cheng L and Li Z: Heterotopic ossification related to the use of recombinant human BMP-2 in osteonecrosis of femoral head. Medicine (Baltimore) 96: e7413, 2017.

51. Mishima H, Sugaya H, Yoshioka T, Aoto K, Wada H, Akaogi $\mathrm{H}$ and Ochiai N: The safety and efficacy of combined autologous concentrated bone marrow grafting and low-intensity pulsed ultrasound in the treatment of osteonecrosis of the femoral head. Eur J Orthop Surg Traumatol 26: 293-298, 2016.

52. Kianmehr N, Bidari A, Mofidi M and Bahar N: Silent osteonecrosis of the femoral head following high-dose corticosteroids in patients with systemic rheumatic diseases. Med J Islam Repub Iran 29: 259, 2015.

53. Jin $\mathrm{H}, \mathrm{Xu}$ T, Chen Q, Wu C, Wang P, Mao Q, Zhang S, Shen J and Tong P: The fate and distribution of autologous bone marrow mesenchymal stem cells with intra-arterial infusion in osteonecrosis of the femoral head in dogs. Stem Cell Int 2016: 8616143, 2016.

54. Sasikumar KP, Elavarasu S and Gadagi JS: The application of bone morphogenetic proteins to periodontal and peri-implant tissue regeneration: A literature review. J Pharm Bioallied Sci 4 (Suppl 2): S427-S430, 2012

55. Bragdon B, Moseychuk O, Saldanha S, King D, Julian J and Nohe A: Bone morphogenetic proteins: A critical review. Cell Signal 23: 609-620, 2011.

56. Hustedt JW and Blizzard DJ: The controversy surrounding bone morphogenetic proteins in the spine: A review of current research. Yale J Biol Med 87: 549-561, 2014.

57. Dagostino PR, Whitmore RG, Smith GA, Maltenfort MG and Ratliff JK: Impact of bone morphogenetic proteins on frequency of revision surgery, use of autograft bone and total hospital charges in surgery for lumbar degenerative disease: Review of the nationwide inpatient sample from 2002 to 2008. Spine J 14: 20-30, 2014.

58. Thawani JP, Wang AC, Than KD, Lin CY, La Marca F and Park P: Bone morphogenetic proteins and cancer: Review of the literature. Neurosurgery 66: 233-246, 2010.

59. Ye L, Bokobza SM and Jiang WG: Bone morphogenetic proteins in development and progression of breast cancer and therapeutic potential (review). Int J Mol Med 24: 591-597, 2009.

60. Uzun G, Mutluoglu M, Ersen O and Yildiz S: Hyperbaric oxygen therapy in the treatment of osteonecrosis of the femoral head: A review of the current literature. Undersea Hyperb Med 43: 189-199, 2016 
61. Wood TJ, Hoppe DJ, Winemaker M and Adili A: Bilateral osteonecrosis of the femoral head during pregnancy following two corticosteroid injections: A case report and review of the literature. Cureus 8: e556, 2016.

62. Hong GJ, Lin N, Chen LL, Chen XB and He W: Association between vascular endothelial growth factor gene polymorphisms and the risk of osteonecrosis of the femoral head: Systematic review. Biomed Rep 4: 92-96, 2016.

63. Papakostidis C, Tosounidis TH, Jones E and Giannoudis PV: The role of 'cell therapy' in osteonecrosis of the femoral head. A systematic review of the literature and meta-analysis of 7 studies. Acta Orthop 87: 72-78, 2016.

64. Wang B, Geng Q, Hu J, Shao J, Ruan J and Zheng J: Platelet-rich plasma reduces skin flap inflammatory cells infiltration and improves survival rates through induction of angiogenesis: An experiment in rabbits. J Plas Surg Hand Surg 50: 239-245, 2016.

65. Radke S, Battmann A, Jatzke S, Eulert J, Jakob F and Schutze N: Expression of the angiomatrix and angiogenic proteins CYR61, CTGF and VEGF in osteonecrosis of the femoral head. J Orthop Res 24: 945-952, 2006.

66. Lebouvier A, Poignard A, Cavet M, Amiaud J, Leotot J, Hernigou P, Rahmouni A, Bierling P, Layrolle P and Rouard $\mathrm{H}$ : Development of a simple procedure for the treatment of femoral head osteonecrosis with intra-osseous injection of bone marrow mesenchymal stromal cells: Study of their biodistribution in the early time points after injection. Stem Cell Res Ther 6: 68, 2015.
67. Chiu WC, Lai YP and Chou MY: Humanization and characterization of an anti-human TNF- $\alpha$ murine monoclonal antibody. PLoS One 6: e16373, 2011.

68. Weisman MH: TNF and anti-TNF treatment in rheumatoid arthritis (RA). What we know and what we still need to know. Ryumachi. Rheumatism 37: 142-143, 1997.

69. Elliot MJ, Maini RN, Feldmann M, Long-Fox A, Charles P, Katasikis P, Brennan FM, Bijl H, Ghrayeb J and Woody JN: Treatment of rheumatoid arthritis with chimeric monoclonal antibodies to tumor necrosis factor alpha. Arthritis Rheum 58 (2 Suppl): S92-S101, 2008.

70. Segal B, Rhodus NL and Patel K: Tumor necrosis factor (TNF) inhibitor therapy for rheumatoid arthritis. Oral Surg Oral Med Oral Pathol Oral Radiol Endod 106: 778-787, 2008.

71. Wang J, Wang K, Shi Z and Zhang M: Osteoprotegerin mRNA/receptor activator of NF-kappaB ligand mRNA expressions in bone tissues of glucocorticoid-induced osteonecrosis of the femoral head. Zhongguo Xiu Fu Chong Jian Wai Ke Za Zhi 22: 1161-1164, 2008 (In Chinese).

This work is licensed under a Creative Commons Attribution-NonCommercial-NoDerivatives 4.0 International (CC BY-NC-ND 4.0) License. 